\title{
Anti-inflammatory Activity Test of Astaxanthin Extract from Litopenaeus vannamei Shrimp Waste Against the Number of Neutrophils and Lymphocytes in White Rats (Rattus norvegicus) Injected with Carrageenin
}

Graciela Carina Najoan ${ }^{1}$, Aniek Prasetyaningsih ${ }^{1 *}$, Vinsa Cantya Prakasita ${ }^{1}$, Abner Amadeuz Wisaksono ${ }^{1}$, Djoko Rahardjo

${ }^{1}$ Department Biology, Faculty of Biotechnology, Duta Wacana Christian University, Jl. Dr. Wahidin Sudirohusodo No.5-25, Kotabaru, Kec. Gondokusuman, Kota Yogyakarta, Daerah Istimewa Yogyakarta 55224

*Corresponding author: Aniek Prasetyaningsih

Shrimp is one of the main export commodities in Indonesia which has the potential to have bioactive compounds. Shrimp waste contains carotenoids, one of which is astaxanthin, a red-orange xanthophyll carotenoid which has potential pharmacological effects including anti-inflammatory. The purpose of this study was to test the anti-inflammatory activity of astaxanthin extract from Litopenaeus vannamei shrimp waste against the decrease in the number of neutrophils and lymphocytes in carrageenin-injected white rats. Tests carried out in this study include extraction, qualitative tests using Thin Layer Chromatography (TLC), Salkowski test, quantitative tests using UV-Vis spectrophotometry, High Performance Liquid Chromatography (HPLC), purification using column chromatography, and preclinical tests using edema models of white rat feet with $1 \%$ carrageenin injection and various doses of the fraction given were $50 \mathrm{mg} / \mathrm{kgBW}, 100 \mathrm{mg} / \mathrm{kgBW}$ and $150 \mathrm{mg} / \mathrm{kgBW}$, positive control (celexocib $18 \mathrm{mg} / \mathrm{kgBW}$ ) and a negative control (propylene glycol $1 \mathrm{ml}$ ). The relative values of neutrophils and lymphocytes per 100 cells were statistically analyzed using SPSS, with a repeated measure ANOVA for the parametric test and Friedman test for the non-parametric test. The results showed that Litopenaeus vannamei shrimp waste extract contained terpenoids and astaxanthin with concentrations of $0.52 \mathrm{mg} / \mathrm{gr}$ crude extract and $220.77 \mathrm{mg} / \mathrm{g}$ fraction. The results of parametric and non-parametric analysis ( $p>0.05$ ) showed that there was no significant difference between each treatment in the decrease of the relative value of neutrophils and lymphocytes, at 0,4 and 8 hour. The relative value of neutrophils and lymphocytes was still within the normal limit, which might also indicate that fraction did not change the relative value of neutrophils and lymphocytes which can cause neutrophilia (increased neutrophils) or neutropenia (decreased neutrophils) and lymphocytopenia (decreased lymphocytes) or lymphocytosis (increased lymphocyte).

Keywords: Astaxanthin, Litopenaeus vannamei Waste, Anti-inflammatory, Neutrophils, Lymphocytes.

Copyright $(\mathbb{2} 2021$ The Author(s): This is an open-access article distributed under the terms of the Creative Commons Attribution 4.0 International License (CC BY-NC 4.0) which permits unrestricted use, distribution, and reproduction in any medium for non-commercial use provided the original author and source are credited.

\section{INTRODUCTION}

The large marine ecosystem in Indonesia provides the opportunities for the use of marine resources as a source of bioactive compounds, one of which is the potential as an active medicinal ingredient. One of the marine biota that has been the main export commodity and holds the potential of bioactive compounds is shrimp. Yogyakarta Special Region is one of the top 15 provinces in Indonesia that produce vannamei shrimps. In 2015 it produced 3,364 tons of vannamei shrimps. The production centers are located in Kulon Progo, Bantul and Gunung Kidul districts [1]. The processed shrimp for export commodities produces waste such as heads, skins, tails and legs of $35 \%-50 \%$ of the total weight, and the waste of frozen, canned and cracker shrimp ranges from $30 \%-75 \%$ of the total weight of shrimp [2]. These shrimp wastes have not been optimally utilized, which then cause pollution and quite high level of Biochemical Oxygen Demand (BOD), Chemical Oxygen Demand (COD) and Total suspended solids (TSS) contents in the waters around the factories $[2,3]$.

Astaxanthin and its esters are the dominant carotenoids in shrimp that contribute $63.5-92.2 \%$ of the total carotenoid content in the analyzed shrimp [4], the shell of vannamei shrimp (Litopenaeus vannamei) contains $94 \mathrm{mg}$ astaxanthin [5]. Astaxanthin (3,3'-dihydroxy- $\beta, \quad \beta$-carotene- $4,4^{\prime}$ - $\quad$ dione) is a red-orange carotenoid pigment in marine biota found in 
salmon, shrimp and micro algae Haematococcus pluvialis. The presence of keto and hydroxyl groups in astaxanthin makes it contains higher biological activity than other carotenoids, it even contains much more antioxidants than $\beta$-carotene or even $\alpha$-tocopherol does $[6,7]$. Astaxanthin has been widely researched and even traded, because it has potential pharmacological effects, such as anticancer, anti-diabetes, antioxidant activity, neurological, cardiovascular, and anti-inflammatory effects [6]. Research on the pharmacological effects of astaxanthin from vannamei shrimp waste as an anti-inflammatory has been done before, the results showed that the purified astaxanthin reduced or suppressed NO (Nitric oxide) production, and also at a dose of $100-150 \mathrm{mg} / \mathrm{kgBW}$ it significantly suppressed the increase in the thickness of the mice legs that were injected with carrageenin, at 2 and 6 hours after injection $[5,8]$. The other test of pharmacological effect as anti-inflammatory can also be seen on the condition of white blood cells (leukocytes), especially the leucocyte differential. Leukocytes play an important role in the systemic inflammatory response to infection, injury, polytraumatic shock and severe shock [9]. Increased levels of neutrophils and lymphocytes in the blood film are a marker of inflammation if these levels are above the normal threshold [10]. Therefore, this study tried to make use of vannamei shrimp (Litopenaeus vannamei) waste as a source of bioactive astaxanthin compounds, specifically for anti-inflammatory seen from the decrease in differential leukocytes, namely the relative value of neutrophils and lymphocytes.

\section{MATERIALS AND METHOD Extraction}

Vannamei shrimp (Litopenaeus vannamei) waste in the form of skin was dried using an oven at $50^{\circ} \mathrm{C}$ for 24 hours. The dried shrimp shells were then mashed and extracted using $70 \%$ ethanol at a ratio of $1: 10$ for 3 days. Evaporation was done using a rotary evaporator at $40^{\circ} \mathrm{C}$ at $55 \mathrm{rpm}$ for approximately 6 hours.

\section{Qualitative test using Thin Layer Chromatography (TLC)}

A crude extract of 20 microliters was spotted on the Merck's TLC silica gel $60 \mathrm{~F}_{254}$ plate, the mobile phase used was petroleum ether: ethanol (8:2), the spray reagent used was anisaldehyde. The stains formed were observed under Ultra Violet (UV) light.

\section{Purification using column chromatography}

The 0.5 grams of crude extract was put in a glass tube using a dropping pipettes. The mobile phase used was petroleum ether: ethanol $(8: 2)$ and the stationary phase is Merck's silica gel 60 (0.063-0.200 $\mathrm{mm})$.

\section{Salkowski test}

The Salkowski test was carried out to identify terpenoid compounds in crude extracts. 0.3 grams of crude extract was put into a test tube, then $2 \mathrm{ml}$ of chloroform and $3 \mathrm{ml}$ of concentrated sulfuric acid was added into the tube. This addition of concentrated sulfuric acid and chlorophome changed the color of the extract and formed a layer.

\section{Quantitative test using UV-Vis spectrophotometry}

The spectrophotometry of crude extract samples and column chromatography fraction were carried out at a wavelength of $477 \mathrm{~nm}$. Curve was created by making a standard stock solution of astaxanthin with a concentration of 5 ppm using Sigma-Aldrich standard astaxanthin from algae Haematococcus pluvialis $(\geq$ $97 \%$ ). The next step was diluting the stock solution to determine the concentration of the standard curve, namely the concentration of $0.6 \mathrm{ppm}, 1 \mathrm{ppm}, 1.4 \mathrm{ppm}$, $1.8 \mathrm{ppm}$, and $2.2 \mathrm{ppm}$. Measurement of astaxanthin concentration in crude extract and chromatography column fraction was carried out by adding the absorbance results of crude extract and fraction in the standard curve regression equation.

\section{High Performance Liquid Chromatography (HPLC)}

HPLC analysis was carried out at the Integrated Laboratory of the Islamic University of Indonesia, Yogyakarta using the LC-2030 Shimadzu Japan, consisting of an LC-2030 pump, an LC-2030 UV detector with a wavelength of $477 \mathrm{~nm}$, a flow rate of $1 \mathrm{ml} / \mathrm{min}$, the mobile phase used was water, methanol and acetonitrile and injection volume of $20 \mu 1$.

\section{Preclinical Test}

Animals used in this study were 20 white male rats (Rattus novergicus), aged 8-12 weeks with a body weight of 180-200 grams. The rats were acclimatized first in the laboratory environment for 3 days and then randomly divided into 5 groups. Feeding used standard feed and drinking ad libitum.

This study has obtained a statement of ethical eligibility from the Ethics Commission for Medical Research, Faculty of Medicine, Duta Wacana Christian University, number: 1207 / C.16 / FK / 2020.

\section{Treatment}

The treatment was given orally. The treatments used were positive control with $18 \mathrm{mg} /$ $\mathrm{kgBW}$ celexocib drug, negative control with propylene glycol $1 \mathrm{ml}$, then treatment of chromatography column fraction results with a dose of $50 \mathrm{mg} / \mathrm{kgBW}$, a dose of $100 \mathrm{mg} / \mathrm{kgBW}$, and a dose of $150 \mathrm{mg} / \mathrm{kgBW}$. The injection of $1 \%$ carrageenin as much as $0.1 \mathrm{ml}$ in sub-plantar rat feet was carried out one hour after treatment.

\section{Blood sampling}

Blood was collected three times, the first time was at hour 0 which is before injection of $1 \%$ carrageenin as much as $0.1 \mathrm{ml}$ in sub-plantar rat feet. The second and third times were at the 4th and 8th hours after 
Graciela Carina Najoan et al., Sch Acad J Biosci, May, 2021; 9(5): 123-129

the carrageenin injection. Blood sampling at 0,4 , and 8 hours were carried out through the caudal vein of the tail. Blood smear preparation

Blood from the caudal vein of the tail was dripped onto a glass objects. The blood smear preparations were air-dried before proceeded to the staining process using methanol for 5 minutes. After that the giemsa dye was dripped on all parts of the blood film and left for 45 minutes, rinsed using distilled water, air-dried and observed using a light microscope.

\section{Observation and analysis of the number of neutrophils and lymphocytes}

Observations were made under a microscope at $1000 \mathrm{x}$ magnification. Neutrophils and lymphocytes were observed and counted per 100 cells using a hand counter.

\section{DATA ANALYSIS}

The results obtained were analyzed using SPSS with repeated measures ANOVA test for parametric tests and friedman test for non-parametric tests.

\section{RESULT AND DISCUSSION Extraction}

Extraction of vannamei shrimp (Litopenaeus vannamei) waste used ethanol as a solvent which can extract many compounds including the terpenoid class compounds. In addition, ethanol is also safer because it has a lower level of toxicity than other solvents $[11,12]$. The extraction method was maceration which is the simplest extraction technique and can be used to extract thermolable compounds including carotenoids. The temperature used in the extraction was room temperature [13]. This extraction using the maceration method and ethanol solvent obtained a crude extract of 25 grams with a yield of $15.52 \%$. The crude extract was thick and orange-reddish in color.

\section{Qualitative test using Thin Layer Chromatography (TLC)}

The crude extract results were identified qualitatively using Thin Layer Chromatography (TLC) as an initial step to determine a good solvent ratio in the separation of compounds, for further use in the purification of astaxanthin using column chromatography. The TLC results showed that there was a separation of compounds seen from the presence of bands or stains that formed on the TLC plate after being observed in Ultra Violet (UV) light (Figure 1).

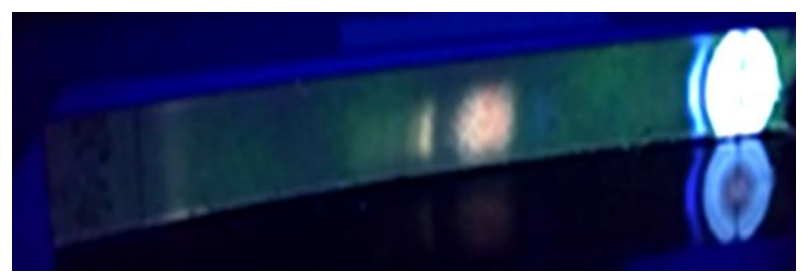

Fig-1: UV TLC results of crude extract, using petroleum ether: ethanol solvent (8:2)

\section{Salkowski Test}

The results of the Salkowski test showed color change to a reddish brown and a layer was formed. A reddish brown color showed positive results of the presence of terpenoids in the crude extract.

\section{Separation of compounds by column chromatography}

This research used column chromatography method to separate and purify astaxanthin compounds from crude extracts. The results of purification using column chromatography obtained 5 fractions with orange to clear yellow color. The fractions then were measured for their astaxanthin content using UV-Vis spectrophotometry.

\section{Quantitative testing of astaxanthin}

The spectrophotometry used in this research was UV-Visible spectrophotometry, namely the absorption of UV light at a wavelength of 180-390 nm, and visible light at a wavelength of 390-780 nm. Astaxanthin is included in carotenoids; carotenoids have of two types, namely xanthophyll and carotene, which provide aborbance in the $400-550 \mathrm{~nm}$ area [14]. The concentration of astaxanthin in the crude extract and the fraction result of the chromatography column was calculated using the regression equation of the standard astaxanthin curve, namely $y=0.0245 x-0.0039$ (Figure 2).

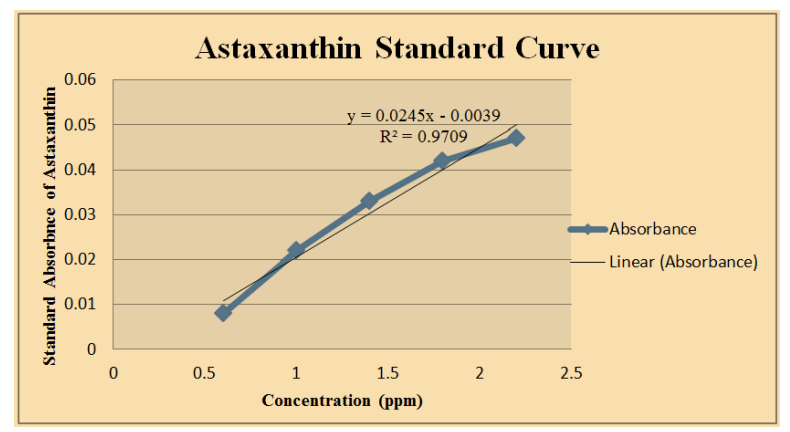

Fig-2: Standard curve for the determination of astaxanthin concentration at a wavelength of $477 \mathrm{~nm}$

Table-1: The concentration of astaxanthin in the crude extract and fraction

\begin{tabular}{|l|l|l|}
\hline Sample & Absorbance & $\begin{array}{l}\text { Astaxanthin } \\
\text { concentration }(\mathbf{m g} / \mathbf{g})\end{array}$ \\
\hline $\begin{array}{l}\text { Crude } \\
\text { extract }\end{array}$ & $0.009 \mathrm{~A}$ & 0,52 \\
\hline Fraction & $0.008 \mathrm{~A}$ & 220,77 \\
\hline
\end{tabular}

The calculation results showed that the astaxanthin content in the crude extract and the chromatography column fraction was quite high. The astaxanthin content in the crude extract was $0.52 \mathrm{mg}$ astaxanthin/gr crude extract and the astaxanthin content in the chromatography column fraction was $220.77 \mathrm{mg}$ 
astaxanthin/gr fraction. The astaxanthin concentration in the fraction was higher than the astaxanthin concentration in the crude extract, this was probably because the fraction was the result of purification which results were purer than the crude extract that still contained other compounds. The relatively high concentration of astaxanthin in the fraction of the chromatography column results was in line with the research of Sowmya and Sachindra [15] which showed that the column fraction had a higher astaxanthin content compared to crude extract, that astaxanthin contributed $92 \%$ of the total carotenoids in fraction 3 , while fraction 2 contained $69.7 \%$ astaxanthin ester, and the astaxanthin content in crude extract was $66.7 \%$. Thus it can also be seen that astaxanthin and its esters contributed 63.5$92.2 \%$ of the total carotenoid content in shrimp [4].

\section{High Performance Liquid Chromatography (HPLC)}

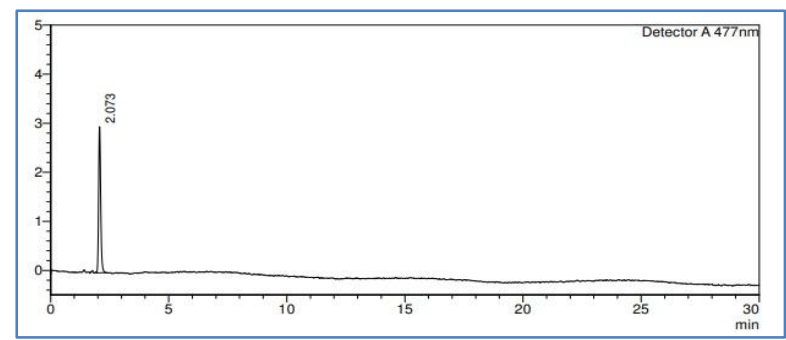

Fig-3: Standard HPLC results for astaxanthin with a retention time (tR) of 2.073 and a peak area of 18354

High Performance Liquid Chromatography was performed to further confirm the presence of astaxanthin in the chromatography column results. HPLC was carried out against the standard Sigma-Aldrich astaxanthin from Haematococcus pluvialis algae ( $\geq 97 \%$ ), to compare the results with the HPLC sample fraction results. The following figures 3 and 4 are the results of HPLC analysis for both standard and sample fractions.

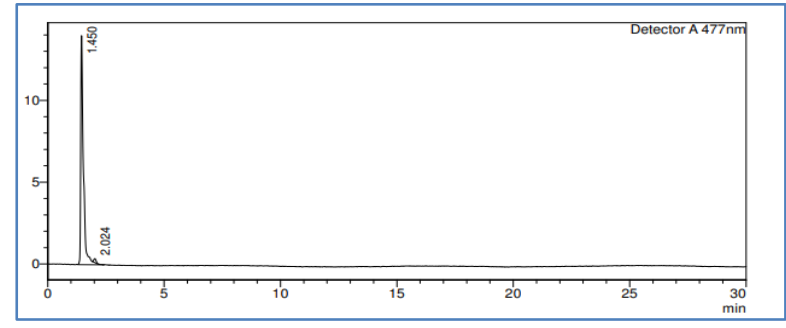

Fig-4: The results of HPLC fractions with retention times (tR) of 1,450 and 2,024 and peak areas of 111180 and 1663

The standard astaxanthin HPLC result only had one peak with a retention time of 2,073 minutes, while for the sample fraction there were two peaks with a retention time of 1,450 and 2,024. When compared, the 2,024 minutes of retention time was closest to the standard retention time. These results could not ascertain whether the compound which has a retention time approaching the standard was astaxanthin. The peak produced for the compound at the retention time of 2,024 was very small, which also showed that the concentration of the compound was very small or smaller when compared to compounds that had a retention time of 1,450 minutes with a higher peak. These results also showed that the sample fraction still contained other compounds, this was because the purification process using a chromatography column had not been able to completely purify the astxanthin from the crude extract sample, further processing was needed to obtain purer astaxanthin.

Preclinical test of anti-inflammatory activity of astaxanthin from vannamei shrimp waste against the number of neutrophils and lymphocytes of white rats Inflammation is the main response of the immune system to infection and irritation caused by physical trauma, chemical substances or microbiological agents, but in certain circumstances inflammation can cause serious illness. Inflammation is caused by the release of pro-inflammatory cytokines such as tumor necrosis factor- $\alpha$ (TNF- $\alpha$ ), interleukin-1 $\beta$ (IL-1 $\beta$ ), and interleukin-6 (IL-6), as well as inflammatory mediators, including nitric oxide (NO) and prostaglandins E2 (PGE2), which is synthesized by nitric oxide synthase (iNOS) and cyclooxygenase (COX) [10]. Besides that, the activation of NF- $\kappa$ B plays an important role in the expression of enzymes associated with inflammation (because it activates coding of pro-inflammatory genes), iNOS and COX-2, as well as cytokines, TNF- $\alpha$ and IL-1 $\beta$ [16]. Leukocyte cells that play a role in acute inflammation are neutrophils, which are the first defense against infection and one of the main cell types involved in the initiation of the inflammatory response. In addition, an increase in neutrophil and lymphocyte levels in the blood film is a marker of inflammation if the level is above the threshold normal limits [17, 10]. The inflammatory model used in this study was edema in rat feet (Figure 5) and the parameters observed were leukocyte (White blood cells) differentials, which was the relative value of neutrophils and lymphocytes. The model of inflammatory edema in carrageenin-injected mouse feet has been used for many purposes including helping to assess the contribution of mediators involved in vascular changes associated with inflammation /accute inflammation [18]. The development of edema in the rats' feet due to carrageenin injection occurs in a biphasic ( 2 phase), in both phases the mediator acts to produce an inflammatory response [18]. The initial phase occurs at $0-1$ hours, after carrageenin injection, the mediators that play a role or are involved in the initial phase are histamine, serotonin, and bradykinin and also a small proportion of prostaglandins produced by the enzyme cyclooxygenase (COX). The next phase, after 1 hour (second phase), the mediators involved in this phase are prostaglandins as well as various cytokines such as IL-1 $\beta$, IL-6, IL-10, and TNF- $\alpha$, as well as neutrophil infiltration $[19,20]$. 


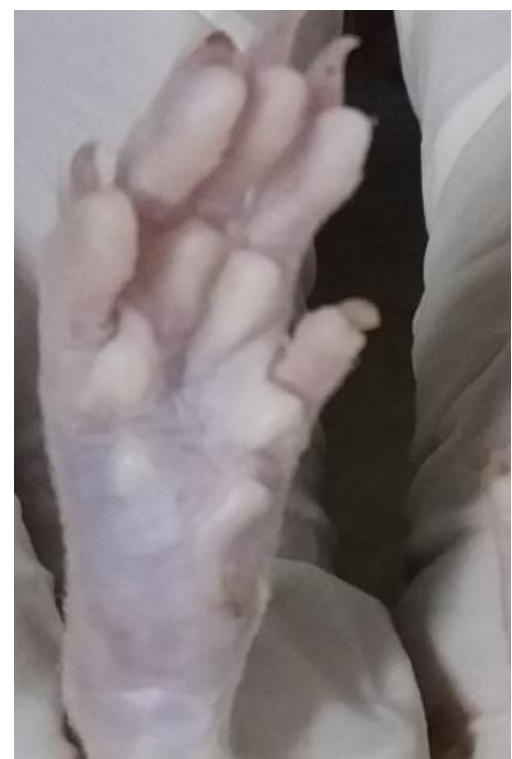

Fig-5: Edema in the rats 'feet after $0.1 \mathrm{ml}$ injection of $1 \%$ carrageenin in the sub-plantar rats' feet

Table 2 below shows the relative values of neutrophils and lymphocytes per 100 cells observed using a light microscope.

Table-2: Relative values of neutrophils and lymphocytes in various treatments over time

\begin{tabular}{|l|l|l|l|l|}
\hline \multirow{2}{*}{ No. } & Treatment & \multicolumn{3}{|l|}{ Result of Neutrophil Relative Value $(\%)$} \\
\cline { 3 - 5 } & & 0 hour & 4th hour & 8th hour \\
\hline 1. & Dose $50 \mathrm{mg} / \mathrm{kgBW}$ & $20.75 \pm 7.411$ & $27 \pm 11.690$ & $30 \pm 7.071$ \\
\hline 2. & Dose $100 \mathrm{mg} / \mathrm{kgBW}$ & $39.75 \pm 11.325$ & $40.75 \pm 9.215$ & $27.25 \pm 23.215$ \\
\hline 3. & Dose $150 \mathrm{mg} / \mathrm{kgBW}$ & $29.75 \pm 17.017$ & $30.25 \pm 5.315$ & $32.25 \pm 17.652$ \\
\hline 4. & Positive control & $28.75 \pm 5.620$ & $34 \pm 9.416$ & $36.75 \pm 9.179$ \\
\hline 5. & Negative control & $26 \pm 10.296$ & $34.25 \pm 8.261$ & $32.75 \pm 11.147$ \\
\hline No. & Treatment & Results of Lymphocyte Relative Value (\%) \\
\cline { 3 - 5 } & & 0 hour & 4th hour & 8th hour \\
\hline 1. & Dose $50 \mathrm{mg} / \mathrm{kgBW}$ & $72.5 \pm 7.371$ & $59.5 \pm 11.210$ & $64.25 \pm 6.449$ \\
\hline 2. & Dose $100 \mathrm{mg} / \mathrm{kgBW}$ & $56.75 \pm 10.720$ & $54.75 \pm 11.871$ & $70.5 \pm 22.338$ \\
\hline 3. & Dose $150 \mathrm{mg} / \mathrm{kgBW}$ & $71.25 \pm 6.292$ & $61.25 \pm 2.217$ & $59.25 \pm 17.340$ \\
\hline 4. & Positive control & $52.25 \pm 2.630$ & $64.25 \pm 15.521$ & $51.75 \pm 9.535$ \\
\hline 5. & Negative control & $63.75 \pm 10.243$ & $52.25 \pm 5.909$ & $61.5 \pm 10.472$ \\
\hline
\end{tabular}

Note: Mean \pm Std. Deviation

Based on statistical analysis, each treatment did not provide significant results ( $>$ > 0.05), which means that there was no significant difference between each treatment towards the decrease of the mean relative value of neutrophils and also the retalive value of lymphocytes, from time to time; 0,4 th and 8 th hour. The mean relative values of neutrophils and lymphocytes in Table 2 also show that there was no clear or significant decrease in the mean relative value of neutrophils and lymphocytes from 0,4 th and 8th hour. The first factor that possibly affected the results were blood instability, including leukocytes which are blood types that are labile because they can be influenced by several factors such as aging, stress, and malnutrition [21]. This factor was minimized by good experimental animal conditioning. The second factor that is also likely to influence the results of blood counts using a peripheral blood smear is described by Durbin et al. [22] These include different phlebotomists, as well as varying lengths and thickness of the blood smears. The peripheral blood smear is a manual method for counting leukocyte cells, one of which is error-prone due to its small field of view, compared to using automatic methods such as flow cytometry which is capable of counting a larger number of leukocyte cells, so that the reading of the number of leukocytes in the sample is statistically more accurate [23]. Carrageenin $1 \%$ may also be a factor that affected the results of the relative value of neutrophils and lymphocytes. There is a possibility that carrageenin at a concentration of $1 \%$ does not provide a sufficient inflammatory effect in mice, so that the relative values of neutrophils and lymphocytes from time to time did not make a significant difference, it can even be said that the values were still considered normal.

The relative mean value of neutrophils was still in the range of normal relative values, namely the lowest was $20.75 \%$ at the 0 hour and the highest was $40.75 \%$ at 
the 4th hour. This value is in accordance with the relative value of normal neutrophils in male rats, which is in the range of $10 \%$ to $40 \%$ [24], which means that neither neutrophilia (increased neutrophils) nor neutropenia (decreased neutrophils) occured. Therefore, these results also showed that the fraction of the refined chromatography column did not have an effect on changes in the relative value of neutrophils at 0,4 and 8 hours which show inflammation if there is an increase in the relative number of neutrophils or decreased neutrophils (neutropenia) which can also be caused by chemotherapy treatments, adverse drug reactions, or autoimmune disorders [25]. The results of the statistical test for the relative value of lymphocytes also showed that each treatment did not have a significant effect on the mean relative values of lymphocytes at 0,4 and 8 hours. The relative value of lymphocytes was still within normal limits, namely the was $72.5 \%$ at the 0th hour and the lowest was $51.75 \%$ at the 8th hour, as in the literature, the range of relative values for normal lymphocytes in male rats is $53 \%-85 \%$ [24 ]. The relative value of lymphocytes, which were still within the normal range, could also indicate that the fraction did not change the relative value of lymphocytes which can results in lymphocytopenia (decreased lymphocytes) or lymphocytosis (increased lymphocytes). Therefore, in this study, although the results of the fraction did not have an anti-inflammatory effect because there was no decrease in the mean relative value of neutrophils and lymphocytes from the 0th hour, 4th hour and 8th hour, but it can be seen that the given treatment, the fraction, did not cause neutrophilia (increased neutrophils) or neutropenia (decreased neutrophils) and lymphocytopenia (decreased lymphocytes) or lymphocytosis (increased lymphocytes). However, previous studies have shown that astaxanthin, which results from the purification of $\mathrm{L}$. vannamei shrimp waste extract, can reduce or suppress NO (Nitric oxide) production [5]. In addition, at a dose of 100-150 mg / $\mathrm{kgbb}$, it significantly suppresses the increase in the thickness of the legs of mice injected with carrageenin at the 2nd and 6th hours after injection [8]. Astaxanthin also has the potential to be anti-inflammatory by suppressing the production of cytokines and inflammatory mediators such as inhibiting the expression of iNOS, COX-2, TNF- $\alpha$, and IL- $1 \beta$ as well as NO and PGE2 production in Lipopolysaccharide-stimulated macrophages (LPS) and BALB / c mice treated with Lipopolysaccharide [26]. Suggestions for further research are to use methods capable of counting leukocyte cells in a larger number, and the carrageenin concentration in further research can be increased for inflammation induction and if necessary, a preliminary test is carried out before preclinical testing.

\section{CONCLUSION}

L.Vannamei shrimp waste contains
astaxanthin and also terpenoid compounds. The
astaxanthin content in the crude extract was $0.52 \mathrm{mg}$ astaxanthin/gr crude extract while the chromatography column fraction was $220.77 \mathrm{mg}$ astaxanthin/gr fraction. Based on the HPLC results, the sample fraction still contained other compounds. The doses of the $50 \mathrm{mg} / \mathrm{kgBW}$ fraction, $100 \mathrm{mg} / \mathrm{kgBW}$ and $150 \mathrm{mg} / \mathrm{kgBW}$ did not yet have an anti-inflammatory effect, as seen from the absence of a decrease in the mean relative value of neutrophils and the relative value of lymphocytes from 0 , 4th and 8th hours of treatments, however the fraction did not cause neutrophilia (increased neutrophils) or neutropenia (decreased neutrophils) and lymphocytopenia (decreased lymphocytes) or lymphocytosis (increased lymphocytes).

\section{REFERENCES}

1. Peta sentra produksi perikanan budidaya. Accessed on

https://ojk.go.id/sijaring/id/sektor-kelautan-dan-peri kanan/usaha-perikanan-budidaya/Dokumen\%20Us aha/peta\%20sentra\%20budidaya\%202016.pdf

2. Armstrong, A. L., BIRCH, B. P., \& Jenkins, J. D. (1994). Renal arteriovenous fistula following blunt trauma. British journal of urology (Print), 73(3), 321-322.

3. Judhaswati, R. D., \& Damayanti, H. O. (2018). Kelayakan Usaha Pengolahan Limbah Kulit Udang dan Rajungan (Studi di Kabupaten Situbondo dan Banyuwangi Provinsi Jawa Timur). Cakrawala: Jurnal Litbang Kebijakan, 12(2), 118-136.

4. Sachindra, N. M., Bhaskar, N., \& Mahendrakar, N. S. (2005). Carotenoids in different body components of Indian shrimps. Journal of the Science of Food and Agriculture, 85(1), 167-172.

5. Santos, S. D., Cahú, T. B., Firmino, G. O., de Castro, C. C., Carvalho Jr, L. B., Bezerra, R. S., \& Filho, J. L. L. (2012). Shrimp waste extract and astaxanthin: rat alveolar macrophage, oxidative stress and inflammation. Journal of Food Science, 77(7), H141-H146.

6. Davinelli, S., Nielsen, M.E., Scapagnini, G. (2018). Astaxanthin in Skin Health, Repair, and Disease: A Comprehensive Review. Nutrients, 10(4):522.

7. Higuera-Ciapara, I., Felix-Valenzuela, L., \& Goycoolea, F. M. (2006). Astaxanthin: a review of its chemistry and applications. Critical reviews in food science and nutrition, 46(2), 185-196.

8. Kuedo, Z., Sangsuriyawong, A., Klaypradit, W., Tipmanee, V., \& Chonpathompikunlert, P. (2016). Effects of astaxanthin from Litopenaeus vannamei on carrageenan-induced edema and pain behavior in mice. Molecules, 21(3), 382.

9. Zahorec, R. (2001). Ratio of neutrophil to lymphocyte counts-rapid and simple parameter of systemic inflammation and stress in critically ill. Bratislavske lekarske listy, 102(1), 5-14.

10. Enjelina, M. Uji Antiinflamasi Kombinasi Astaxanthin dan Vitamin C terhadap Jumlah Neutrofil dan Limfosit pada Tikus Putih Galur Wistar yang diinduksi Karagenin. Jurnal Mahasiswa PSPD FK Universitas Tanjungpura, 1(2). 
11. Gupta, A., Naraniwal, M., \& Kothari, V. (2012). Modern extraction methods for preparation of bioactive plant extracts. International journal of applied and natural sciences, 1(1), 8-26.

12. Azis, T., Febrizky, S., \& Mario, A. D. (2014). Pengaruh Jenis Pelarut Terhadap Persen Yieldalkaloiddari Daun Salam India (Murraya Koenigii). Jurnal Teknik Kimia, 20(2).

13. Zhang, Q. W., Lin, L. G., \& Ye, W. C. (2018). Techniques for extraction and isolation of natural products: A comprehensive review. Chinese medicine, 13(1), 1-26.

14. Novoveská, L., Ross, M. E., Stanley, M. S., Pradelles, R., Wasiolek, V., \& Sassi, J. F. (2019). Microalgal carotenoids: A review of production, current markets, regulations, and future direction. Marine drugs, 17(11), 640.

15. Sowmya, R., \& Sachindra, N. M. (2012). Evaluation of antioxidant activity of carotenoid extract from shrimp processing byproducts by in vitro assays and in membrane model system. Food Chemistry, 134(1), 308-314.

16. Kiemer, A. K., Hartung, T., Huber, C., \& Vollmar, A. M. (2003). Phyllanthus amarus has anti-inflammatory potential by inhibition of iNOS, COX-2, and cytokines via the NF- $\kappa B$ pathway. Journal of Hepatology, 38(3), 289-297.

17. Rosales, C., Lowell, C. A., Schnoor, M., \& Uribe-Querol, E. (2017). Neutrophils: their role in innate and adaptive immunity 2017.

18. Salvemini, D., Wang, Z. Q., Wyatt, P. S., Bourdon, D. M., Marino, M. H., Manning, P. T., \& Currie, M. G. (1996). Nitric oxide: a key mediator in the early and late phase of carrageenan- induced rat paw inflammation. British journal of pharmacology, 118(4), 829-838.
19. Crunkhorn, P., \& Meacock, S. C. R. (1971). Mediators of the inflammation induced in the rat paw by carrageenin. British journal of pharmacology, 42(3), 392-402.

20. Gilligan, J. P., Lovato, S. J., Erion, M. D., \& Jeng, A. Y. (1994). Modulation of carrageenan-induced hind paw edema by substance P. Inflammation, 18(3), 285-292.

21. Takanari, J., Hirayama, Y., Homma, K., Miura, T., Nishioka, H., \& Maeda, T. (2015). Effects of active hexose correlated compound on the seasonal variations of immune competence in healthy subjects. Journal of evidence-based complementary $\&$ alternative medicine, 20(1), 28-34.

22. Durbin, C., Guo, K., Hoffman, W., Eric Schultze, A., \& White, S. (2009). Estimating leukocyte, platelet, and erythrocyte counts in rats by blood smear examination. Veterinary clinical pathology, 38(2), 157-162.

23. Chung, J., Ou, X., Kulkarni, R. P., \& Yang, C. (2015). Counting white blood cells from a blood smear using Fourier ptychographic microscopy. PloS one, 10(7), e0133489.

24. Jacob Filho, W., Lima, C. C., Paunksnis, M. R. R., Silva, A. A., Perilhão, M. S., Caldeira, M., ... \& de Souza, R. R. (2018). Reference database of hematological parameters for growing and aging rats. The Aging Male, 21(2), 145-148.

25. Munshi, H.G., Montgomery, R.B. (2000). Severe neutropenia: a diagnostic approach. The Western journal of medicine, 172(4):48-252.

26. Lee, S. J., Bai, S. K., Lee, K. S., Namkoong, S., Na, H. J., Ha, K. S., \& Kim, Y. M. (2003). Anti-Inflammatory. Mol Cells, 16(1), 97-105. 